\title{
Prevalence and Associated Risk Factors of Ovine Oestrosis in Dendi District of Central Ethiopia
}

\author{
Askale Gizaw (D)', Petros Admasu (D)², Achalu Nagasa ${ }^{3}$, Solomon Shiferaw', Morka Dandecha Bayu', \\ Adem Abdella ${ }^{3}$ \\ 'Department of Veterinary Laboratory Technology, Ambo University, Ambo, Oromia, Ethiopia; ${ }^{2}$ Department of Veterinary Science, Ambo University, \\ Ambo, Oromia, Ethiopia; ${ }^{3}$ Department of Veterinary Medicine, Haramaya University, Harar, Oromia, Ethiopia \\ Correspondence: Askale Gizaw, Department of Veterinary Laboratory Technology, Ambo University, P.O. Box 19, Ambo, Oromia, Ethiopia, \\ Tel +25I-940047577, Email askalegizaw2I@gmail.com
}

Background: Ovine oestrosis is an economically important and widely distributed parasitic disease of sheep that is caused by Oestrus ovis larvae across the world. Despite the fact that Oestrus ovis is a common parasite in Ethiopia and that there are many sheep in the study area, there is no information on the prevalence, larval burden, predilection sites, and risk factors associated with Oestrus ovis infestation in sheep in the Dendi district of West Shewa Zone, Ethiopia.

Methods: A cross-sectional study was conducted from November 2017 to April 2018, to estimate the prevalence, risk factors, and larval burden, and identify common predilection sites for Oestrus ovis larvae. A total of 180 sheep heads were randomly selected from five purposely selected restaurants in Ginchi town, Dendi district, transported to the laboratory, opened with a hand saw, and visually examined for infestations. The larvae were collected from positive sheep heads and counted. The sites where the larvae were obtained were recorded. The data were analyzed using SPSS version 20 software.

Results: Of the total of 180 examined sheep heads, 104 (57.8\%) were infested with larvae of Oestrus ovis. In the study, a statistically significant difference $(\mathrm{p}>0.05)$ was not observed in the prevalence of Oestrus ovis in relation to all considered risk factors such as sex, age, and origin of sheep. From 104 infested sheep, a total of 664 larvae were detected in different parts of sheep heads. The mean larval intensity per infected animal with Oestrus ovis was 6.38. In this study, the minimum and maximum numbers of larvae recovered were 1 and 26, respectively. The nasal cavity, nasal sinus and frontal sinus were the predilection sites of Oestrus ovis larvae identified in this study.

Conclusion: Oestrosis is an important and common parasitic disease of sheep in the study area.

Keywords: Dendi, Ethiopia, Oestrus ovis, ovine, prevalence, risk factors

\section{Introduction}

Myiasis is an infestation of tissue and organs of animals or man with dipteran fly larvae. ${ }^{1-3}$ Oestrosis is a myiasis caused by dipteran flies of the family Oestridae, genus Oestrus, and species of Oestrus ovis. O. ovis, the sheep bot fly, is an economically important, obligatory parasite of the nasal cavities and adjoining sinuses of sheep and goats. ${ }^{3,4}$ Oestrosis is primarily a disease of sheep, which are widely distributed across the world. Goats are less affected than sheep. Other animals, including humans, are also affected. ${ }^{2,5}$

The $O$. ovis infestation phase arises when the adult fly starts to deposit the larvae. Larvae pass through three stages or instars. ${ }^{6}$ The female $O$. ovis fly is viviparous and deposits L1 in or around the nostrils. Inside the nasal cavities, the first instar larvae attach to the mucous membrane, change to second instars, move up to the sinuses and molt to L3. Finally, mature third instar larvae return to the nasal passage, are expelled out by the sneezing action of the host, and pupate in the soil to give rise to further generations of adults. ${ }^{2,5}$

Oestrus ovis is a problem for sheep and goats worldwide. ${ }^{6}$ Both adult and larval stages have an effect on the host. The activities of adult flies during the deposition of larvae cause annoyance, which results in loss of body condition. ${ }^{2,5}$ Infestation by larvae of $O$. ovis causes great irritation to the host which results from mechanical activity of the mouth 
hooks and larval spines as well as the effect of proteolytic enzymes excreted or secreted by $O$. ovis larvae. The damage caused by the larval stage depends on the number of larvae and the site of infestation. ${ }^{2}$ The activities of larvae in sheep cause nasal discharge, sneezing and dyspnea. Death of larvae inside the sinus predisposes sheep to secondary bacterial infection. Larvae sometimes migrate into the brain of sheep and cause in coordination called "false gid"., 4

Oestrosis in small ruminants causes substantial economic losses to sheep and goat producers. ${ }^{6,7}$ The pathogenic effects cause a reduction in production and serious economic losses, which have been estimated at 1.1-4.6 kg of meat, $200-500 \mathrm{~g}$ of wool, and up to $10 \%$ of milk per animal. ${ }^{2}$ Mozaffari et $\mathrm{al}^{7}$ also reported a $10 \%$ mortality rate of sheep with O. ovis infestation. Besides, oestrosis has public health significance. In humans, O. ovis larvae infestation causes ocular myiasis (ophthalmomyiasis) ${ }^{8}$ and, rarely, nasal myiasis. ${ }^{9,10}$

In Ethiopia, a few studies were conducted on ovine oestrosis. Prevalence of $77.42 \%$ in Debre Zeit area, Central Ethiopia, ${ }^{11}$ 94.6\% in Central Oromia ${ }^{12}$ and $69.8 \%$ in Ambo were reported in sheep. ${ }^{13}$ These shows, $O$. ovis are a common and important parasite of sheep in the country. Moreover, presence of large number of sheep population, conducive climatic conditions for the parasite to complete its life cycle, extensive grazing system used in which the animal on pasture throughout all months of the year and increased production systems in the country create ideal conditions for the spreading out of this type of parasitism in small ruminants. Although, the impact of $O$. ovis on sheep producer is known, larval burden, prevalence and risk factors associated with parasite distribution are not known in Dendi district. An assessment of the current situation of ovine oestrosis in the study area will provide baseline information against the diseases and plays a significant role in designing strategic control toward the parasites. Therefore, the objectives of this study were to estimate the prevalence, larval burden, risk factors associated with $O$. ovis infestation and predilection site of the larvae in sheep slaughtered at Ginchi town, Dendi district of West Shoa Zone, Ethiopia.

\section{Materials and Methods Study Area}

The study was conducted from November 2017 to April 2018 in the Dendi district of the West Shewa Zone, Oromia regional state, Ethiopia. Dendi district is located $79 \mathrm{~km}$ from Addis Ababa with an elevation ranging from 2000 to 3288 meters above sea level. Geographically, the district lies within the coordinates of $8^{\circ} 43^{\prime} \mathrm{N}-9^{\circ} 17^{\prime} \mathrm{N}$ and $37^{\circ} 47^{\prime} \mathrm{E}-38^{\circ}$ $20^{\prime} \mathrm{E}$. Dendi is bordered on the west by Ambo, on the east by Ejerie, on the north by Jeldu and on the south by the Southwest Shewa Zone. The administrative town of Dendi district is Ginchi. The temperature ranges from $9.3-23.8^{\circ} \mathrm{C}$ and the annual rainfall of the Dendi district ranges from 750-1170 mm. The number of sheep in the West Shewa Zone was estimated to be around $1,028,162 .^{14}$

\section{Study Animal}

The study was carried out in sheep bought for slaughter by restaurant owners of Ginchi town, Dendi district, West Shewa Zone, Oromia regional state, Ethiopia. The sheep slaughtered here came from surrounding kebeles of the district. For the prevalence study, only apparently healthy animals able to be slaughtered and both female and male with the age reached for slaughter (approximately 6 months and above) were included in the study. Dentation was used to estimate the age of each sheep, ${ }^{15}$ which was then divided into two groups: adult ( $>1$ year) and young ( 1 year) to determine the presence of age-related O. ovis larvae infestation. ${ }^{12}$ Information on the origin and sex of the sheep was obtained from restaurant owners.

\section{Study Design}

A cross-sectional study was conducted to estimate the prevalence and risk factors associated with $O$. ovis in sheep in the study area, as well as to determine the larvae burden and preferred site of $O$. ovis larvae.

\section{Sampling Technique}

Five restaurants found in Ginchi town, Dendi district, West Shewa were selected purposively. Weekly visits to selected restaurants private slaughter slabs were made to collect the samples. Slaughtered sheep heads were randomly selected from each of the selected restaurants. 


\section{Collection and Examination of Sheep Heads}

Heads of selected sheep were put into separate plastic bags, labeled, stored in the icebox and transported to the laboratory of Veterinary Laboratory Technology, Guder Mamo Mezemir Campus, Ambo University, for examination. In the laboratory, the skin was removed and the head was parted longitudinally into two symmetrical parts by using a hand saw, ${ }^{11-13}$ and inspected visually for infestation. From positive sheep heads, all existing larvae were collected using forceps and counted. The site in which the larvae were found was recorded.

\section{Data Analysis}

The collected data were entered into a Microsoft Excel spread sheet. The Statistical Package for the Social Sciences (SPSS) version 20 software was used to analyze the data. A Chi-square test $\left(x^{2}\right)$ was used to determine the statistical significance of the association of $O$. ovis infection with sex, age, and origin of sheep. The statistical analysis was considered significant at $\mathrm{p}<0.05$.

\section{Results}

From the total of 180 examined sheep heads, $104(57.8 \%)$ were infested with larvae of $O$. ovis. The prevalence of $O$. ovis larvae infestation based on the sex, age, and origin of sheep were summarized in Table 1. In the present study, there was no significant variation $(\mathrm{p}>0.05)$ of $O$. ovis infection between sexes, age, and origin of sheep.

\section{Larvae Burden of Oestrus ovis}

The larvae found in all positive sheep heads were counted and recorded. From 104 infested sheep, a total of 664 larvae were detected in different parts of sheep heads. The mean larval intensity per infected sheep was 6.38. In this study, the number of recovered larvae ranged from 1 to 26 . The maximum and minimum numbers of larvae detected in this study were 26 and 1 , respectively (Table 2 ).

\section{Predilection Sites of Oestrus ovis Larvae}

The nasal cavity, frontal sinus, and nasal sinus were the predilection sites of the detected $O$. ovis larvae in the current study. Smaller numbers of larvae were recovered from the nasal cavities of sheep (Table 3).

\section{Discussions}

This study revealed that $O$. ovis is a common and important parasite of sheep in the study area. In the current study, an overall $57.8 \%$ prevalence of $O$. ovis infestation was recorded in sheep. On the contrary, higher prevalence were reported by Yilma, Genet ${ }^{11}$ in Debre Zeit, Central Ethiopia; Gebremedhin ${ }^{13}$ in Ambo; and Alem et al ${ }^{12}$ in Central Oromia,

Table I Prevalence of Oestrus ovis Infection on Basis of Sex, Age and Origin of Sheep

\begin{tabular}{|c|c|c|c|c|c|c|c|}
\hline Variables & Category & Total Number & No Examined & No. Positive & Prevalence (\%) & $P$ - value & $x^{2}$ \\
\hline \multirow[t]{2}{*}{ Sex } & Female & \multirow{2}{*}{180} & 118 & 66 & 55.9 & \multirow[t]{2}{*}{0.489} & \multirow[t]{2}{*}{0.478} \\
\hline & Male & & 62 & 38 & 61.3 & & \\
\hline \multirow[t]{2}{*}{ Age } & Young & \multirow{2}{*}{180} & 79 & 49 & 62 & \multirow[t]{2}{*}{0.308} & \multirow[t]{2}{*}{1.041} \\
\hline & Adult & & 101 & 55 & 54.5 & & \\
\hline \multirow[t]{4}{*}{ Origin } & Galesa & \multirow{4}{*}{180} & 56 & 33 & 58.9 & \multirow{4}{*}{0.589} & \multirow{4}{*}{1.902} \\
\hline & Asgori & & 44 & 23 & 52.3 & & \\
\hline & Dano & & 41 & 27 & 65.8 & & \\
\hline & Wamura & & 39 & 21 & 53.8 & & \\
\hline
\end{tabular}


Table 2 Mean Larval Burdens in the Heads of Examined Sheep

\begin{tabular}{|l|l|l|l|l|l|}
\hline $\begin{array}{l}\text { No. } \\
\text { Examined }\end{array}$ & $\begin{array}{l}\text { No. } \\
\text { Positive }\end{array}$ & $\begin{array}{l}\text { Mean Larval Count per } \\
\text { Positive }\end{array}$ & $\begin{array}{l}\text { Min. Larvae per } \\
\text { Head }\end{array}$ & $\begin{array}{l}\text { Max. Larvae per } \\
\text { Head }\end{array}$ & $\begin{array}{l}\text { Total Larvae } \\
\text { Count }\end{array}$ \\
\hline 180 & 104 & 6.38 & 1 & 26 & 664 \\
\hline
\end{tabular}

Table 3 Common Predilection Sites of Recovered Oestrus ovis Larvae

\begin{tabular}{|l|c|c|c|}
\hline Predilection Site & No. Positive & The No. of Recovered Larvae & Percent per Total Examined Animal (\%) \\
\hline Frontal sinus & 13 & 116 & 12.5 \\
Nasal sinus & 10 & 51 & 9.6 \\
Nasal cavity & 5 & 10 & 4.8 \\
Frontal sinus and nasal sinus & 23 & 194 & 22.1 \\
Nasal cavity, nasal sinus and frontal sinus & 53 & 293 & 51 \\
\hline Total & $\mathbf{1 0 4}$ & $\mathbf{6 6 4}$ & \\
\hline
\end{tabular}

Ethiopia. The difference in prevalence may be attributed to differences in sample size, study periods, and agroecology like moisture, temperatures, and altitude that create a suitable environment for the nasal bot fly to exist, the absence of treatments against this parasite, and the absence of community awareness of the effect and controlling methods of the parasite in the area. ${ }^{5}$

This study revealed a higher prevalence of ovine oestrosis in relation to the studies conducted in some other countries, which reported $13.7 \%$ in Brazil, ${ }^{16} 40.3 \%$ in North Eastern Turkey, ${ }^{17} 40.83 \%$ in Iraq, ${ }^{18} 19 \%$ in Ecuador, ${ }^{19} 38.71 \%$ in Eastern Turkey. ${ }^{20}$ This might be due to the breed of sheep in other parts of the world being more resistant to oestrosis than the sheep in the study area. The climatic and geographical variations of the study area and other parts of the world might also have created differences in prevalence.

In the current study, a statistically significant difference $(\mathrm{p}>0.05)$ was not observed in the prevalence of $O$. ovis in relation to all considered risk factors such as sex, age, and origin of sheep in the study. This finding is similar to previous reports by Arslan et $\mathrm{al}^{17}$ and Özdal et al. ${ }^{20}$ This might be due to the ability of the $O$. ovis fly to feed on any available animal. ${ }^{2}$ This contradicts previous findings by Abo-Shehada et al; ${ }^{21}$ Shoorijeh et al; ${ }^{22}$ and, Gebremedhin ${ }^{13}$ who found a significant difference in $O$. ovis infestation between males and females. Significant variation in $O$. ovis infestation among young and adults, which is inconsistent with our findings, was reported by Yilma and Genet ${ }^{11} \operatorname{Horak}^{23}$ and Papadopoulos et $\mathrm{al}^{24}$ respectively.

In this study, no statistical difference $(p>0.05)$ was also found between the origins of sheep that were oestrosis positive. This might be due to the similarity of climatic conditions, which are an important factor for the distribution of the fly between the origins of the sheep. ${ }^{5,25}$ This finding agreed with that of Murguía et $\mathrm{a}^{26}$ in the Central Region of Yucatan, Mexico; Negm-Eldin et $\mathrm{al}^{27}$ in the Green Mountain area of Libya, Saleem et $\mathrm{al}^{28}$ in north India, which were insignificant with respect to the origin.

The current study revealed that there is a 6.38 mean larval burden of the $O$. ovis infestation in sheep. This disagrees with previous investigators' findings by Caracappa et al, ${ }^{29}$ Gebremedhin, ${ }^{13}$ Silva et al, ${ }^{16}$ Scala et al, ${ }^{30}$ Alcaide et al ${ }^{31}$ who reported higher mean larval burdens from infected sheep. The differences might have originated from climatic and seasonal differences between the study areas and the immune state of the sheep. Poor management, presence of internal and external parasite infestation are also factors that aggravate the $O$. ovis infestation. The stocking density of the flock will also influence the infection of $O$. ovis. ${ }^{4,5,32}$

O. ovis larvae were found in the nasal sinus, frontal sinus, and nasal cavity in the current study. Similar to our finding, the nasal and frontal sinus sites of $O$. ovis larvae was reported by Silva et al. ${ }^{16}$ Occurrence of $O$. ovis larvae in the nasal cavity of sheep was reported by Allaie et al. ${ }^{3}$ 


\section{Conclusions and Recommendations}

The prevalence of ovine oestrosis was identified for the first time in the study area, and the prevalence obtained was high. This indicates oestrosis is a common parasitic disease of sheep found in the Dendi district. Our study revealed that no statistical difference $(\mathrm{p}>0.05)$ was found between age, sex, and origins of the animal and $O$. ovis infestation in sheep. The mean larval intensity per infected sheep was 6.38. During this study, the nasal cavity, frontal sinus and nasal sinus of sheep were identified as predilection sites of $O$. ovis larvae. Based on the above conclusions, the following facts are recommended: The seasonal variations in the distribution of $O$. ovis should be studied. Veterinary extension should be expanded to reduce $O$. ovis prevalence using appropriate antihelminthics and insect repellent insecticides.

Farmer's awareness programs on the effects, prevention, and control methods of $O$. ovis infestation should be created.

\section{Data Sharing Statement}

All additional data used in the present study are available from the first author and corresponding author.

\section{Acknowledgments}

This study was funded by Ambo University. The authors deeply acknowledge Ambo University for financial support and providing other needed services for the study. The author greatly acknowledges the administrator of the Dendi district livestock and fishery development office, the restaurant owners of Ginchi town and the personnel working in the slaughtering slabs for their cooperation during the study.

\section{Author Contributions}

All authors made a significant contribution to the work reported, whether that is in the conception, study design, execution, acquisition of data, analysis and interpretation, or in all these areas; took part in drafting, revising or critically reviewing the article; gave final approval of the version to be published; have agreed on the journal to which the article has been submitted; and agree to be accountable for all aspects of the work.

\section{Disclosure}

The authors declare that there are no conflicts of interest in this work.

\section{References}

1. Sucilathangam G, Meenakshisundaram A, Hariramasubramanian S, Anandhi D, Palaniappan N, Anna T. External ophthalmomyiasis which was caused by sheep botfly (Oestrus ovis) larva: a report of 10 cases. J Clin Diagnostic Res. 2013;7(3):539.

2. Wall R, Shearer D. Veterinary Ectoparasites: Biology, Pathology and Control. Oxford: Blackwells Science. Ltd; 2001.

3. Allaie I, Wani Z, Malik A, Shahardar R, Zulhuma M. Oestrus ovis larvae in nasal cavity of sheep: a case report. J Parasit Dis. 2016;40 (4):1221-1222. doi:10.1007/s12639-015-0655-3

4. Gunalan S, Kamaliah G, Wan S, et al. Sheep oestrosis (Oestrus ovis, Diptera: Oestridae) in Damara crossbred sheep. Malays J Vet Res. 2011;2:41-49.

5. Radostits OM, Gay CC, Hinchcliff KW, Constable PD. Veterinary Medicine, a Textbook of the Diseases of Cattle, Horses, Sheep, Pigs and Goats. 10th ed. Blackwell Science; 2000.

6. Patra G, Biswas P, Sahara A, Behera P, Debbarma A. Nasal myiasis in animals due to Oestridae-a mini review. Inter J Med Phar Drug Res. 2018;2 (4):48-54. doi:10.22161/ijmpd.2.4.1

7. Mozaffari AA, Shojaeepour S, Ghahremani Ghareh Cheshmeh S. High mortality rate due to false gid in a sheep herd. Int Sch Res Notices. 2013. doi:10.1155/2013/650358

8. Dono M, Bertonati MR, Poggi R, et al. Three cases of ophthalmomyiasis externa by sheep botfly Oestrus ovis in Italy. Microbiologica. 2005;28 (4):365-368.

9. Velev V, Mikov O. Ophthalmomyiasis caused by larvae of the parasite Oestrus ovis. QJM: Int J Med. 2018;111(10):727-728. doi:10.1093/qjmed/ hcy 106

10. Fernández S, Hernández-Porto M, Tinguaro V. Ophthalmomyiasis and nasal myiasis by Oestrus ovis in a patient from the Canary Islands with uncommon epidemiological characteristics. Enferm Infecc Microbiol Clin. 2015;35(7):461-462. doi:10.1016/j.eimc.2015.10.003

11. Yilma J, Genet A. Epidemiology of the sheep nasal bot, Oestrus ovis (Diptera: Oestridae), in Central Ethiopia. Rev Med Vet. 2000;151(2):143-150.

12. Alem F, Kumsa B, Degefu H. Oestrus ovis larval myiasis among sheep and goats in Central Oromia, Ethiopia. Trop Anim Health Prod. 2010;42 (4):697-703. doi:10.1007/s11250-009-9477-6

13. Gebremedhin EZ. Prevalence of ovine and caprine oestrosis in Ambo, Ethiopia. Trop Anim Health Prod. 2011;43(1):265-270. doi:10.1007/s11250010-9687-y

14. Dendi Districts Livestock and Fishery Development Office. The annual report. Dendi, Ethiopia; 2016. 
15. Hamito D. Estimation of weight and age of sheep and goats. Ethiopia sheep and goat productivity improvement program (ESGPIP). Technical Bulletin. 2009;23:11.

16. Silva BF, Machado GP, Izidoro TB, Amarante AF. Prevalence of Oestrus ovis (Diptera: Oestridae) in sheep from the São Paulo Central region, Brazil. Rev Bras Parasitol Vet. 2013;22(1):18-21. doi:10.1590/S1984-29612013005000011

17. Arslan MO, Kara M, Gicik Y. Epidemiology of Oestrus ovis infestations in sheep in Kars province of north-eastern Turkey. Trop Anim Health Prod. 2009;41(3):299-305. doi:10.1007/s11250-008-9190-х

18. Mohammed RG, Josef SS, Abed KJ. Prevalence of Oestrus ovis larvae in slaughtered sheep of Misan City, Iraq. Syst Rev Pharm. 2020;11(4):652-655.

19. Ortega-Muñoz G, Luzuriaga-Neira N, Salazar-Silva R, Rodríguez-Hidalgo R. Oestrus ovis in Ecuador: importance in the Andean sheep farming. Vet World. 2019;12(4):522. doi:10.14202/vetworld.2019.522-526

20. Özdal N, Tanritanir P, Ilhan F, Değer S. The prevalence of ovine oestrosis (Oestrus ovis Linnaeus, 1761, Diptera: Oestridae) and risk factors in Eastern Turkey. Vet Arh. 2016;86(3):323-333.

21. Abo-Shehada MN, Batainah T, Abuharfeil N, Torgerson P. Oestrus ovis larval myiasis among goats in northern Jordan. Prev Vet Med. 2003;59(12):13-19. doi:10.1016/S0167-5877(03)00058-8

22. Shoorijeh SJ, Negahban S, Tamadon A, Behzadi MA. Prevalence and intensity of Oestrus ovis in sheep of Shiraz, southern Iran. Trop Anim Health Prod. 2009;41(7):1259-1262. doi:10.1007/s11250-009-9309-8

23. Horak IG. Parasites of domestic and wild animals in South Africa. Oestrid fly larvae of sheep, goats, springbok and black wildebeest in the Eastern Cape Province. Onderstepoort J Vet Res. 2005;72(4):315-320. doi:10.4102/ojvr.v72i4.188

24. Papadopoulos E, Prevot F, Diakou A, Dorchies P. Comparison of infection rates of Oestrus ovis between sheep and goats kept in mixed flocks. Vet Parasitol. 2006;138(3-4):382-385. doi:10.1016/j.vetpar.2006.02.023

25. Cepeda-Palacios R, Scholl P. Factors affecting the larvipositional activity of Oestrus ovis gravid females (Diptera: Oestridae). Vet Parasitol. 2000;91(1-2):93-105. doi:10.1016/S0304-4017(00)00265-X

26. Murguía M, Rodriguez J, Torres F, Segura J. Detection of Oestrus ovis and associated risk factors in sheep from the central region of Yucatan, Mexico. Vet Parasitol. 2000;88(1-2):73-78. doi:10.1016/S0304-4017(99)00204-6

27. Negm-Eldin MM, Elmadawy RS, Hanan GM. Oestrus ovis larval infestation among sheep and goats of Green Mountain areas in Libya. $J$ Adv Vet. 2015;2(4):382-387. doi:10.5455/javar.2015.b105

28. Saleem T, Katoch R, Yadav A, Mir IA, Godara R, Ahamed I. Prevalence of ovine oestrosis in plain and Kandi areas of Jammu, north India. Int J Sci Environ Technol. 2017;6(2):1117-1122.

29. Caracappa S, Rilli S, Zanghi P, Di Marco V, Dorchies P. Epidemiology of ovine oestrosis (Oestrus ovis Linne 1761, Diptera: Oestridae) in Sicily. Vet Parasitol. 2000;92(3):233-237. doi:10.1016/S0304-4017(00)00317-4

30. Scala A, Solinas G, Citterio C, Kramer L, Genchi C. Sheep oestrosis (Oestrus ovis Linné 1761, Diptera: Oestridae) in Sardinia, Italy. Vet Parasitol. 2001;102(1-2):133-141. doi:10.1016/S0304-4017(01)00515-5

31. Alcaide M, Reina D, Sánchez J, Frontera E, Navarrete I. Seasonal variations in the larval burden distribution of Oestrus ovis in sheep in the southwest of Spain. Vet Parasitol. 2003;118(3-4):235-241. doi:10.1016/j.vetpar.2003.09.021

32. Tabouret G, Lacroux C, Andreoletti O, et al. Cellular and humoral local immune responses in sheep experimentally infected with Oestrus ovis (Diptera: Oestridae). Vet Res. 2003;34(2):231-241. doi:10.1051/vetres:2002070

Veterinary Medicine: Research and Reports

\section{Publish your work in this journal}

Veterinary Medicine: Research and Reports is an international, peer-reviewed, open access journal publishing original research, case reports, editorials, reviews and commentaries on all areas of veterinary medicine. The manuscript management system is completely online and includes a very quick and fair peer-review system. Visit http://www.dovepress.com/testimonials.php to read real quotes from published authors.

Submit your manuscript here: http://www.dovepress.com/veterinary-medicine-research-and-reports-journal 